\title{
The Red-Banded Butterfly Lizard, Leiolepis rubritaeniata Mertens 1961 (Sauria: Leiolepididae), A Newly Documented Nonindigenous Species in Florida
}

\author{
Kenneth L. Krysko ${ }^{1}$, Kevin M. Enge ${ }^{2}$, and Claudia A. MacKenzie-Krysko ${ }^{1}$ \\ ${ }^{1}$ Florida Museum of Natural History, University of Florida, Gainesville, Florida 32611, USA (kenneyk@ufl.edu) \\ ${ }^{2}$ Florida Fish and Wildlife Conservation Commission, 1105 SW Williston Road, Gainesville, Florida 32601, USA (e-mail: kevin.enge@myfwc.com)
}

$\mathrm{T}$ he Red-Banded Butterfly Lizard, Leiolepis rubritaeniata Mertens 1961, is indigenous to eastern Thailand, adjacent central and southern Laos, and southern central Vietnam (Peters 1971, Stuart 1999, Darevsky and Nguyen 2004, Hartmann et al. 2012). This diurnal species is characterized by a highly reduced dorsal pattern in males (Grismer et al. 2008, Hartmann et al. 2012). The expandable lateral markings are reduced to the proximate post-axillary region; posterior lateral two-thirds of the flanks are plain reddishorange up to the groin; a lesser degree of dark lateral barring and the edges of dorsal spots are fused in some places; except for a light yellowish post- and subocular stripe, little to no color pattern exists on the side of the head; and especially in older lizards, only a polygonal net-like pattern made of the borders of faded ocelli exists (Grismer et al. 2008, Hartmann et al. 2012). The lateral color pattern of males is an easily observed character used to diagnose species (Peters 1971, Hartmann et al. 2012). Males have the ability to flatten their bodies by expanding their rib cages, in order to dis-
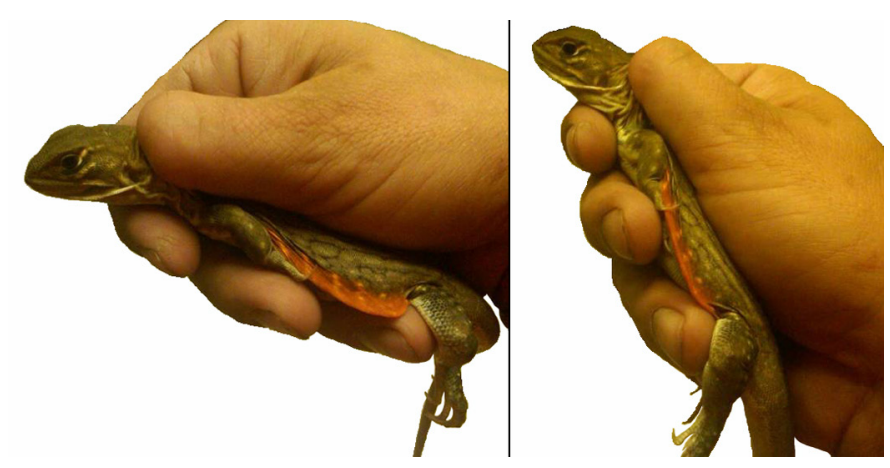

Fig. 1. Red-Banded Butterfly Lizard, Leiolepis rubritaeniata (UFHerpetology 167804), found on Val Mar Drive, Fort Myers, Lee County, Florida, on 25 May 2012. Photographs by Shane Slaughter. play their colorful lateral patterns to enhance visual perception and communication (Hartmann et al. 2012). Leiolepis rubritaeniata is edificarian, but naturally inhabits open, flat, sandy areas within tropical lowland rainforests (Grismer and Grismer 2010, Hartmann et al. 2012). This species constructs an underground burrow with two exits, and when disturbed, it retreats into its burrow and seals the opening with loose sand (Hartmann et al. 2012).

On 25 May 2012, Shane Slaughter collected a Leiolepis rubritaeniata (UF-Herpetology 167804) on Val Mar Drive, Fort Myers, ca. $0.2 \mathrm{~km}$ northwest of State Road 867, Lee County, Florida $\left(26.56259^{\circ} \mathrm{N}, 81.91038^{\circ} \mathrm{W}\right.$, datum WGS84, elev. $2 \mathrm{~m}$ ) (Fig. 1). This lizard was captured while cornered at the juncture of two walls. On 12 July 2012, Melissa Councell photographed a $L$. rubritaeniata (photographic voucher UF-Herpetology 167182) at State Road 867 and Bayside Drive, Fort Myers $\left(26.56383^{\circ} \mathrm{N}, 81.90671^{\circ} \mathrm{W}\right)$ (Fig. 2). This lizard was observed basking on pavement alongside the road. On 7 September 2013 at 1115 h, we observed a juvenile $L$.

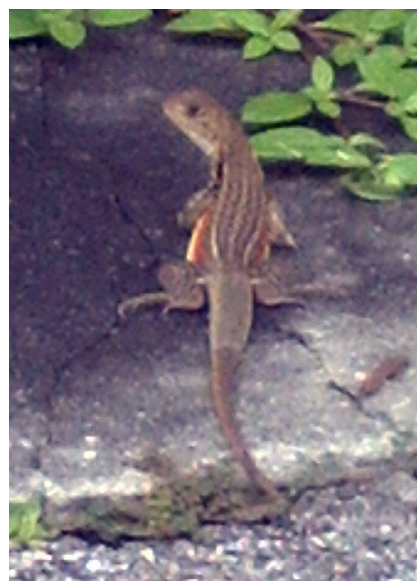

Fig. 2. Red-Banded Butterfly Lizard, Leiolepis rubritaeniata (in situ; UF-Herpetology photographic voucher 167182), found at State Road 867 \& Bayside Drive, Fort Myers, Lee County, Florida, on 12 July 2012. Photograph by Keith Councell. 
rubritaeniata on Bayside Drive, ca. $0.1 \mathrm{~km}$ northwest of State Road $867\left(26.564303^{\circ} \mathrm{N}, 81.907604^{\circ} \mathrm{W}\right)$. This lizard was observed on a well-manicured lawn, and when approached from a vehicle, it quickly retreated into its burrow approximately $1 \mathrm{~m}$ away. At $1140 \mathrm{~h}$, we observed an adult L. rubritaeniata at State Road 867 and Peck Avenue $\left(26.5631^{\circ} \mathrm{N}\right.$, $81.907355^{\circ} \mathrm{W}$ ) (Fig. 3). This lizard was observed on a wellmanicured lawn at the entrance to its burrow, and when approached on foot, it quickly retreated underground. At $1148 \mathrm{~h}$, we returned to this site and photographed this lizard from our vehicle while it basked at its burrow entrance (photographic voucher UF-Herpetology 171120). These observations span a distance of $0.4 \mathrm{~km}$, but the available habitat in the neighborhood is much more extensive.

All Leiolepis rubritaeniata were observed in a highly developed residential area in open areas receiving direct sunlight. This microhabitat is similar to that of its only known introduced congener, the Butterfly Lizard (Leiolepis belliana Hardwicke and Gray 1827), in Florida (Krysko and Enge 2005). Leiolepis rubritaeniata appears to be quite wary of pedestrians, but like other cautious lizard species (i.e., Leiolepis belliana, Agama agama africana, Ctenosaura spp., Iguana iguana), it allows an observer in a vehicle to get much closer before retreating. Leiolepis rubritaeniata in Florida likely was released or escaped from pet owners or dealers, and because both juveniles and adults have been found for a period of $>1$ year, this species might be established (i.e., reproducing; stage 3 following Colautti and MacIsaac 2004).

\section{Acknowledgments}

We thank Wolfgang Böhme for species confirmation; Louis A. Somma for geographic distributions and assistance with references; Shane Slaughter and Keith and Melissa Councell for depositing vouchers in the FLMNH; and Gad Perry, Robert Powell, and an anonymous reviewer for helpful comments on this paper.

\section{Literature Cited}

Colautti, R.I. and H.J. MacIsaac. 2004. A neutral terminology to define 'invasive' species. Diversity and Distributions 10:135-141.

Darevsky, I.S. and V.S. Nguyen. 2004. Geographic distribution: Leiolepis reevesii rubritaeniata. Herpetological Review 35:288.

Grismer, J.L. and L.L. Grismer. 2010. Who's your mommy? Identifying maternal ancestors of asexual species of Leiolepis Cuvier, 1829 and the description of a new endemic species of asexual Leiolepis Cuvier, 1829 from southern Vietnam. Zootaxa 2433:47-61.

Grismer, L.L., T. Neang, T. Chav, P.L. Wood, Jr., J.R. Oaks, J. Holden, J.L. Grismer, T.R. Szutz., and T.M. Youmans. 2008. Additional amphibians and reptiles from Phnom Samkos Wildlife Sanctuary in northwestern Cardamom Mountains, Cambodia, with comments on their taxonomy and the discovery of three new species. The Raffles Bulletin of Zoology 56:161-175.

Hartmann, T., S. Sothanin, M. Handschuh, and W. Böhme. 2012. The taxonomic status of the Red-banded Butterfly Lizard Mertens 1961, with distributional and natural history notes. Russian Journal of Herpetology 19:108-11.

Krysko, K.L. and K.M. Enge. 2005. A new non-native lizard in Florida, the Butterfly Lizard, Leiolepis belliana (Sauria: Agamidae). Florida Scientist 68:247-249.

Stuart, B.L. 1999. Amphibians and Reptiles, pp. 43-67. In: J.W. Duckworth, R. E. Salter, and K. Khounboline (eds.), Wildlife in Lao PDR: 1999 Status Report. IUCN-The World Conservation Union, Vientiane.

Peters, G. 1971. Die intragenerischen Gruppen und die Phylogenese der Schmetterlingsagamen (Agamidae: Leiolepis). Zoologische Jahrbücher. Abteilung für Systematik, Ökologie und Geographie der Tiere 98:11-130.

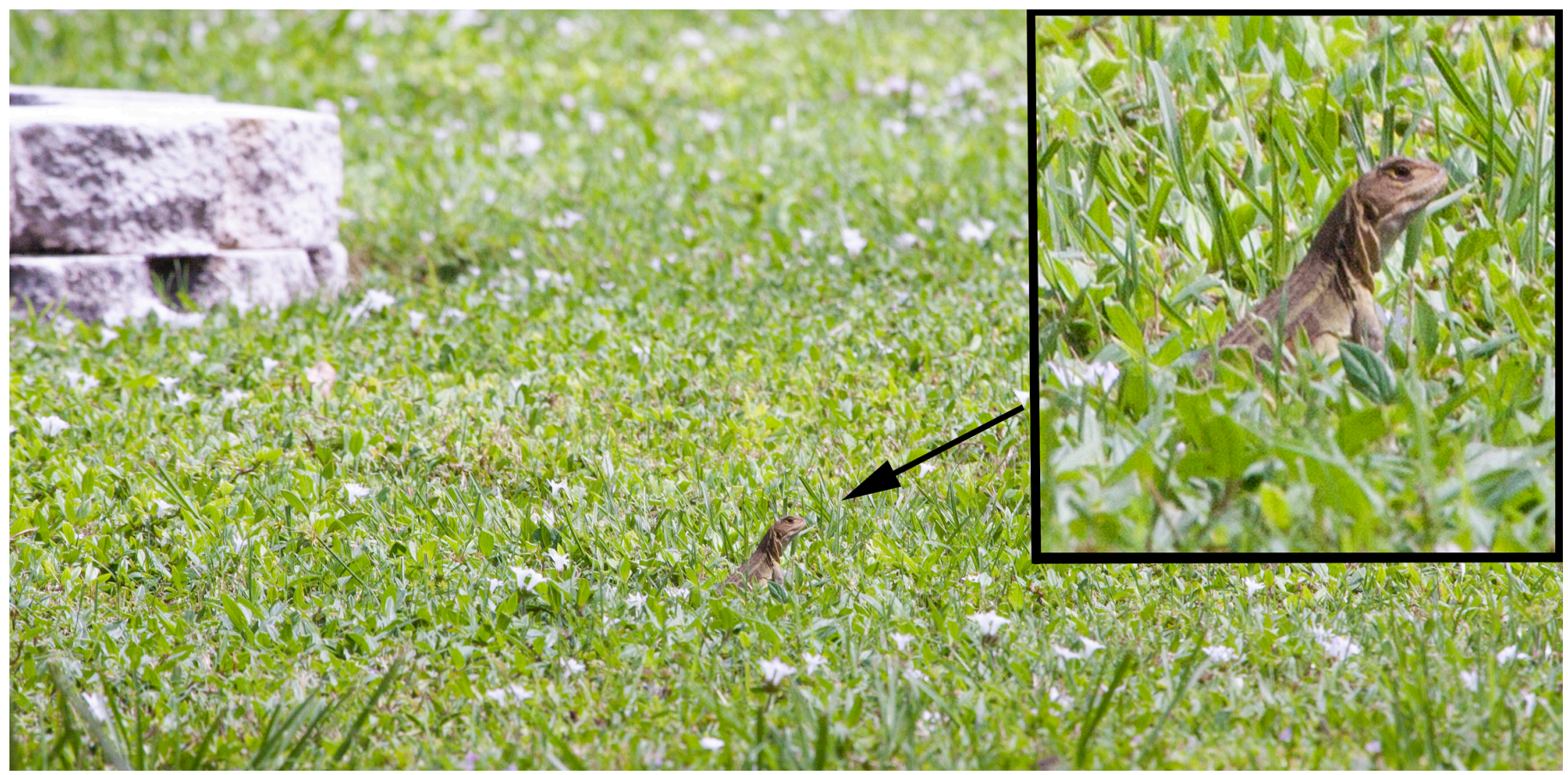

Fig. 3. Red-Banded Butterfly Lizard, Leiolepis rubritaeniata (in situ; UF-Herpetology photographic voucher 171120), found at State Road 867 and Peck Avenue, Fort Myers, Lee County, Florida, on 7 September 2013. Photograph by Kenneth L. Krysko. 